\title{
BUILDING THE COVID-19 TESTING CAPACITIES IN CROATIA: ESTABLISHING THE INTERDEPARTMENTAL COVID-19 UNIT AT THE SPLIT UNIVERSITY HOSPITAL CENTRE
}

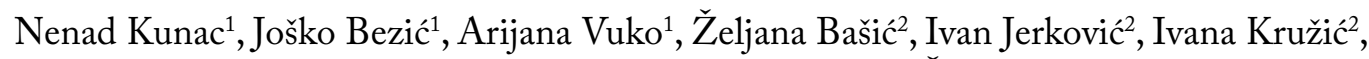 \\ Toni Ljubić 2 , Bernarda Lozić ${ }^{3}$, Sanda Sardelićc ${ }^{4}$ and Šimun Anđelinovićc ${ }^{1,5}$
}

${ }^{1}$ Department of Pathology, Forensic Medicine and Cytology, Split University Hospital Centre, Split, Croatia;

${ }^{2}$ University Department of Forensic Sciences, University of Split, Split, Croatia;

${ }^{3}$ Department of Pediatrics, Split University Hospital Centre, Split, Croatia;

${ }^{4}$ Department of Microbiology and Parasitology, Split University Hospital Centre, Split, Croatia;

${ }^{5}$ School of Medicine, University of Split, Split, Croatia

SUMMARY - This paper presents the chronology, experiences, and challenges in introducing COVID-19 RT-PCR testing in Split, Croatia. We describe the processes from March 12, 2020 to May 26, 2020, starting from the initial knowledge transfer, expert team formation and management, testing implementation, and concluding with the standalone testing facilities, which used automated processes sufficient to meet testing requirements at that time. In the case presented, the COVID-19 unit was organized by joining human and laboratory resources from five clinical departments at the Split University Hospital Centre. Sample preparation procedures and analyses were launched within the restricted time frame while simultaneously training and organizing new laboratory staff and completing equipment requirements. As a result, the process that started with 30 tests per day was constantly improved over time and reached up to 160 tests per day when MagNA Pure was added to automatize RNA extraction at the end of April. At that pace, the cumulative number of samples soon exceeded the first thousand, and by the end of May it exceeded 4000. The case presented provides an example of good practice for crisis response and organization that successfully enabled sufficient COVID-19 testing capacities within the restricted time frame, human and technical resources. Despite limited understanding of COVID-19 at that time, appropriate management, transfer of knowledge, previous experiences in related laboratory and diagnostic work, as well as interdisciplinary and interdepartmental cooperation proved appropriate to overcome the above limitations and ensure adequate healthcare response.

Key words: COVID-19, RT-PCR, Split, Croatia

"Knowing is not enough; we must apply. Wishing is not enough; we must do." Johann Wolfgang von Goethe

Global pandemic of coronavirus disease-19 (COVID-19) has impacted almost every country in the

Correspondence to: Toni Ljubic, $M S$, University Department of Forensic Sciences, University of Split, Ruđera Boškovića 33, HR-21000 Split, Croatia

E-mail: toni.ljubic@unist.hr

Received August 18, 2020, accepted January 25, 2021 world. From the first COVID-19 case in Croatia, reported in Zagreb on February 25, 20201,2, the disease was confirmed in a total of 2244 patients until May 26, $2020^{3}$. The most affected parts of Croatia were the Split-Dalmatia County with a total of 549 confirmed cases and the City of Zagreb as an independent county with a total of 480 confirmed cases ${ }^{3}$. 
Although the first confirmed case was reported in late February, Croatia had established a disease tracking and communication system in late January, as a response to a global health issue that was, at that time, still localized in the Far East ${ }^{2}$. The first test for COVID-19 was performed on January 30, 2020 at Dr Fran Mihaljević University Hospital for Infectious Diseases in Zagreb, the leading institution specialized in infectious diseases in Croatia ${ }^{4}$. Multiple COVID-19 sampling centers were established across the country. Still, sample preparation, extraction, analysis, and interpretation were initially performed only at Dr Fran Mihaljević Hospital. With the increase in the number of tests and spread of the disease across Croatia, an initiative was created to increase testing capacities. This was not only a great challenge from the medical standpoint but also a demanding task in terms of organization and logistics. The increased capabilities and decentralization of the process would considerably affect the healthcare system from the financial aspect, with reduction of transportation costs and the time required to obtain results. As the largest healthcare institution in the second largest county in Croatia, the Split University Hospital Centre (Split UHC) was a logical starting place to expand testing capacities.

Director of the Split UHC and hospital expert team for COVID-19 infection control decided to send a team of doctors and laboratory staff for official visit to Dr Fran Mihaljević Hospital on March 12 and 13, 2020. The purpose of the visit was to get an insight into the testing procedures and requirements and to assess the resources readily available in the Split UHC environment. During the visit, the staff of Dr Fran Mihaljević Hospital led by Professor Alemka Markotić presented details of all stages of testing, including sample receipt, processing and proving the presence of the virus. After the leading institution demonstrated their know-how, the team led by Professor Anđelinović was convinced that the Split UHC had all the necessary human, spatial, and technical resources to introduce the testing.

Upon their return to Split, the team informed the Split UHC Director, who immediately convened a meeting on coordination for the introduction of COVID-19 diagnostics on March 16, 2020, only a day after the first COVID-19 case reported in the SplitDalmatia County 5 . The main conclusions of the meeting were that COVID-19 diagnostics could be intro- duced, but only as an interdepartmental effort of the Split UHC as a whole. Since the virus was a global epidemiologic issue, it was necessary to assemble a team from various medical disciplines. Although the team's knowledge and experience were not directly related to the virus, they had experience in laboratory and diagnostic procedures which they could apply in the new circumstances. This was also a logical point in terms of equipment, and the team concluded that Department of Pathology, Forensic Medicine and Cytology had $80 \%$ of the equipment needed for diagnostics (such as real-time reverse transcription-polymerase chain reaction (RT-PCR) device and a biological safety cabinet for sample preparation), as well as trained laboratory staff. Additionally, Department of Microbiology and Parasitology had a biological safety cabinet for sample handling, which they had previously used for tuberculosis samples, as well as staff trained in similar laboratory procedures. Therefore, the complete project was planned as interdepartmental cooperation between the previously mentioned Department of $\mathrm{Pa}$ thology, Forensic Medicine and Cytology and Department of Microbiology and Parasitology, but also Department of Pediatrics and Department of Gynecology and Obstetrics, which used its expert knowledge and experience from in vitro fertilization procedures as a starting point for their contribution to the Split UHC COVID-19 testing project. Director of the Split UHC appointed the head of the Department of Pathology, Forensic Medicine and Cytology as the main coordinator of the project, who immediately formed a list of Hospital personnel that could contribute to the project. At the meeting held on March 17, 2020 with all the project participants, it was decided for the process to take place at two locations. The first stage, lysis and RNA extraction, would take place at the Department of Microbiology and Parasitology. This part of the Department was temporarily displaced at the Križine Hospital, a separate facility in the eastern part of the Split UHC, which had been previously converted into a COVID-19 respiratory center. This was the central COVID-19 institution in southern Croatia with a capacity of 400 beds. The second stage, PCR amplification and sample analysis, would be performed at the Department of Pathology, Forensic Medicine and Cytology at the Firule Hospital, a separate facility in the western part of the Split UHC. On the next day, March 18, 2020, the first samples were 
delivered from Dr Fran Mihaljević Hospital. At the meeting held on March 20, 2020, it was decided that the first RT PCR tests would be performed in the week from March 23 to March 27, 2020.

The first test and validation at an institution south of the Croatian capital began on March 23, 2020 at Split UHC using the samples received from Dr Fran Mihaljević Hospital. After successful validation, the team started performing independent sample extraction, processing, and analysis on the next day, March 24,2020 . Initially, the interdepartmental COVID unit could complete analysis of around 30 samples per day. To increase the number of processed samples and to mitigate the impact of the potential disease spread, an additional biological safety cabinet for sample extraction was installed inside the sample extraction room at Križine facility. In this way, the number of possible daily sample analyses increased to around 60, starting from March 30, 2020. In the same week, the interdepartmental unit was strengthened by additional staff from the Department of Transfusion Medicine. In the team formation process, it was necessary to simultaneously process and analyze the samples, as well as educate and train new team members with no previous experience with this specific type of infective samples. The final unit structure comprised six pathologists, a pediatrician, and four laboratory staff members in the amplification and analysis team. In comparison, the extraction team included two clinical microbiologists and a resident in clinical microbiology, as well as seven laboratory staff members. Both teams were divided into two sub-teams as a precaution to enable continuous work in case the group members were directly exposed to virus or exhibited symptoms. One amplification and analysis sub-team worked for seven days, while the other one was on standby at home. The extraction and lysis group was similarly organized, but with the work/standby period increased to 14 days.

Virus lysis and RNA extraction in a class 2 biological safety cabinet required four to six hours for a total of 46 samples. This stage also included sample preparation and labelling, data entry, and necessary measures to ensure personal protection of the staff (gloves, face mask, goggles, visor and disposable suit). UV light was also used inside the cabinets for decontamination. Extracted nucleic acid was afterwards amplified using PCR at the Department of Pathology, Forensic Medicine and $\mathrm{Cy}$ tology. The amplified sample was analyzed to detect the presence of two genes, envelope gene (E-gen) as a SARS screening gene, and RdRPGen as a SARSCoV-2 specific confirmatory gene. The sample was confirmed as SARS-CoV-2 positive if the presence of both genes was detected. Final results were interpreted by the pathologists. Upon writing the report, they forwarded it to other hospital departments to inform them about further actions for the patient, as well as the Split UHC Director and all other healthcare and national services included in the COVID crisis management and control. To ensure data distribution and public informing in a timely fashion, testing results were entered in the Hospital Information System (BIS), as well as in the Central Health Information System (CEZIH). This database unified the results from Zagreb and Split, as well as from testing facilities in Rijeka, Zadar and Osijek, which, in the meantime, also initiated testing. It is important to stress that COVID-19 testing was performed not only in the potentially infected individuals but also in medical staff and patients scheduled for various medical procedures.

Shortly after the testing had started at the Split UHC, additional tests were performed at the Teaching Institute of Public Health of Split-Dalmatia County, which could, in the beginning, process around 40 samples per day. These mutual efforts, along with a small proportion of samples sent to Dr Fran Mihaljević University Hospital when needed, provided a total capacity of about 140 samples per day. Testing capacity in the Split UHC increased with the addition of MagNA Pure 96 automated extraction system (Roche Diagnostics, Rotkreuz, Switzerland), which considerably accelerated the process. At that time, it was possible to perform up to 160 tests per day, as MagNA Pure could provide RNA extraction of 96 samples in around one hour. In contrast, before automatization, it took around six hours to extract RNA from 48 samples. To mitigate the spread of infection and sample cross-contamination, prior to MagNA Pure process, sample lysis was performed manually. After RNA extraction, samples were amplified in the RT PCR device, which could process up to 96 samples in around 80 minutes. Besides time benefits it introduced, automated RNA extraction also improved staff safety by reducing their contact with samples. Personnel education in the work with MagNA Pure was conducted on April 21 and 22, 2020 , which resulted in the first fully automated sample extraction process on April 24, 2020. On the same 


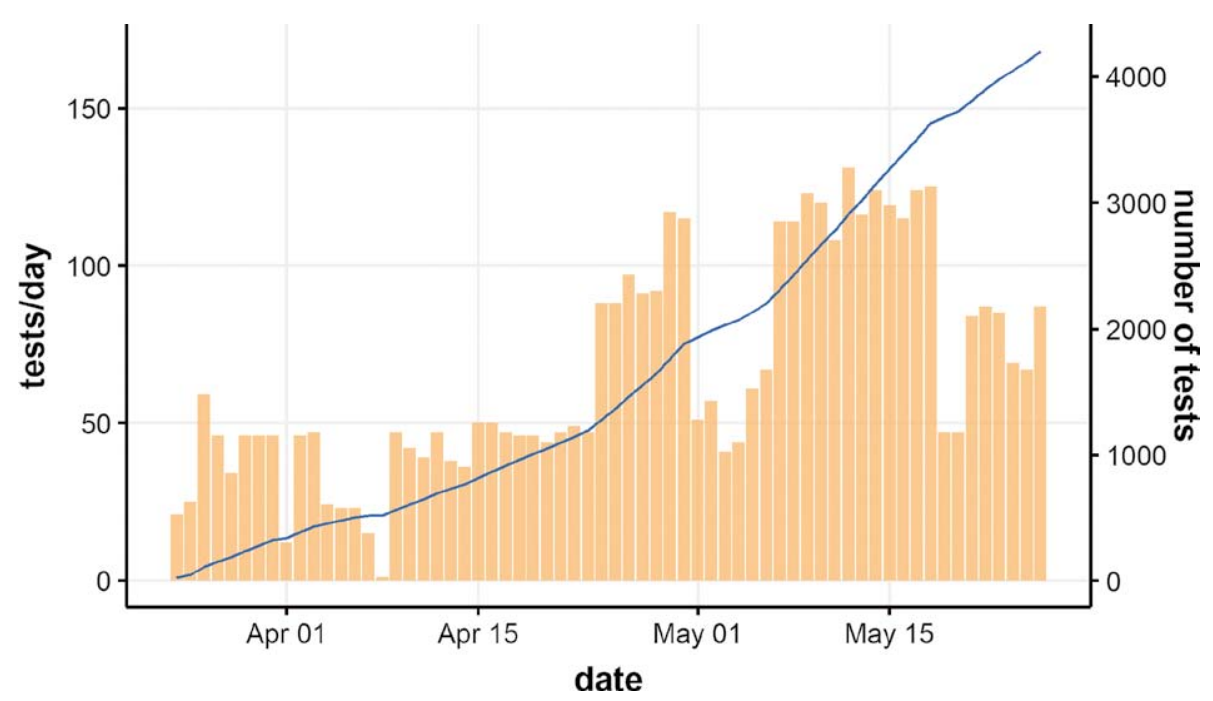

Fig. 1. Number of tests per day and cumulative test number from March 24 to May 26, 2020.

day, a milestone of the first 1000 samples processed at the Split UHC was reached (Fig. 1).

From March 24 to May 26, 2020, the total number of new COVID-19 tests per day was below 10 in Croatia, which may imply that the epidemic was on a decline. This was a result of strict and swift measures set by the Croatian government, but also many efforts made by the healthcare system, and is deemed as one of the best responses to the COVID-19 pandemic on a global scale $^{6}$. This hard-laboring process in the healthcare system, presented in this chronology of the Split COVID unit, was not always in the public spotlight.

Driven by responsibility for public health, members of the Split COVID unit fused their interdisciplinary knowledge and experience to address one of the most severe health challenges of the modern world. Within the restricted time frame, unit members managed to step into a relatively unexplored field. They had to learn and apply knowledge without delay, while simultaneously helping in training of new staff joining the project. Moreover, they also had to collaborate and accept their role in the novel organizational structure outside their home departments. In other case, capacities needed for a successful and timely response would be insufficient. The COVID-19 situation was recognized on time, and actions were made to secure a stable healthcare response in Dalmatia region days before the first confirmed case in the Split-Dalmatia County. The crucial issue at that time was cooperation and knowledge sharing between medical experts from Zagreb and Split. The capacities built in this process ensured a prepared response in the Split-Dalmatia County when no one could foresee that it would become the most affected county in Croatia at a certain point (end of April, 2020). Although the current COVID situation is under control, the knowledge and experience gained from the life cycle of the Split UHC COVID unit could be an example for future dealing with the crisis, management, and organization through lessons learned through interdepartmental cooperation, merging of available human and technical resources, and unified management.

This experience might provide a lesson how to deal with future challenges within the public and national security, in a similar way how the experience from The Homeland War contributed to handle the major crisis in Croatia since the war itself. Specifically, rapid transition from the routine to the pandemic diagnostics was facilitated by previous experience and organization skills developed during the war. At that time, hospitals needed to adapt to accept the increasing number of the wounded but also to enable identification of war victims. Thus, they had to act rapidly to timely respond to all demands placed on them and handle the crisis, in the same way required in the current COVID-19 crisis.

\section{Disclaimer}

This article does not represent in whole or in part the views of the authors' institutions, however, it does express those of the authors. 


\section{References}

1. Čivljak R, Markotić A, Kuzman I. The third coronavirus epidemic in the third millennium: what's next? Croat Med J. 2020;61(1):1-4. doi: 10.3325/cmj.2020.61.1

2. Hrvatski zavod za javno zdravstvo [Internet]. COVID-19Priopćenje prvog slučaja [cited June 15, 2020] Available from: https://www.hzjz.hr/priopcenja-mediji/covid-19-priopcenjeprvog-slucaja/. (in Croatian)

3. Koronavirus.hr [Internet]. News 2020 [cited June 15, 2020]. Available from: https://www.koronavirus.hr/najnovije/. (in Croatian)
4. Hrvatski Sabor. Prijedlog zakona o izmjenama i dopunama $\mathrm{Za}$ kona o zaštiti pučanstva od zaraznih bolesti, s Konačnim prijedlogom zakona (April 9,2020). Available from: https://www. sabor.hr/sites/default/files/uploads/sabor/2020-04-09/183402 /PZ_921.pdf. (in Croatian)

5. Koronavirus.hr [Internet]. Split-Dalmatia County [cited June 15, 2020]. Available from: https://www.koronavirus.hr/podaci /489?filtered=1\&zupanija_id=164\&dobna_skupina=\&fbclid=I wAR1FKIYoarYQZT3xfXtrGIN7SicNcKQ8p5flbVOVKj YUqGeRAbpFE5BdWck. (in Croatian)

6. Hale T, Webster S. Oxford COVID-19 Government Response Tracker [Internet] [cited June 15, 2020]. Available from: https://covidtracker.bsg.ox.ac.uk/stringency-scatter.

Sažetak

\title{
RAZVOJ KAPACITETA ZA TESTIRANJE NA COVID-19 U HRVATSKOJ: POKRETANJE MEĐUODJELNE JEDINICE COVID-19 U KLINIČKOME BOLNIČKOM CENTRU SPLIT
}

\author{
N. Kunac, J. Beziç, A. Vuko, Ž. Bašić, I. Jerković, I. Kružić, T. Ljubić, B. Lozić, S. Sardelić i Š. Anđelinović
}

Cilj je ovoga rada prikazati kronologiju, iskustva i izazove tijekom uvođenja testiranja na COVID-19 pomoću RT-PCR-a u Splitu. Rad obuhvaća razdoblje od 12. ožujka do 26. svibnja 2020., počevši od početnoga prijenosa znanja, osnivanja i organiziranja timova, provedbe testiranja pa sve do uvođenja automatizacije procesa koja je na koncu omogućila potpuno zadovoljavanje tadašnjih potreba. U predmetnome slučaju jedinica COVID-19 utemeljena je objedinjavanjem ljudskih potencijala i laboratorijskih kapaciteta iz pet kliničkih zavoda Kliničkoga bolničkog centra Split. Pokrenuti su procesi pripreme i analize uzoraka, dok se istodobno radilo na obučavanju i organiziranju novoga osoblja te upotpunjavanju potrebne opreme i uređaja. Kao rezultat rada, početni kapaciteti od 30 testova na dan stalno su se povećavali, dostigavši krajem travnja razinu i do 160 testova nakon nabavke uređaja MagNA Pure za automatsku ekstrakciju RNK-a. Tim tempom kumulativni broj provedenih testova ubrzo je dostigao 1000, dok je do kraja svibnja prešao i 4000. Opisani slučaj prikazuje primjer dobre prakse odgovora i upravljanja krizom koji su omogućili stvaranje dostatnih testnih kapaciteta za COVID-19 uz ograničeno vrijeme, osoblje i tehničke resurse. Bez obzira na skromnost tadašnjih saznanja o bolesti COVID-19, odgovarajući načini upravljanja, prijenosa znanja, prethodnoga iskustva u srodnome laboratorijskom i dijagnostičkom radu, kao i interdisciplinarna i međuodjelna suradnja polučili su dobre rezultate u premošćivanju opisanih izazova te osiguravanju primjerenoga odgovora zdravstvenog sustava.

Ključne riječi: COVID-19, RT-PCR, Split, Hrvatska 